\title{
Effect of Fertigation on Productivity and Economics of Dwarf Coconut cv. Chowghat Orange Dwarf (COD)
}

\author{
S. Rani ${ }^{*}$, C. Sudhalakshmi ${ }^{1}$, K. Venkatesan ${ }^{1}$ and H.P. Maheshwarappa ${ }^{2}$ \\ ${ }^{1}$ Coconut Research Station, Aliyarnagar - 642104 (Tamil Nadu), India \\ ${ }^{2}$ ICAR-CPCRI, Kasaragod - 671124 (Kerala), India \\ *Corresponding author
}

\section{Keywords \\ Fertigation, Tender nut yield, Economics \\ Article Info \\ Accepted: \\ 12 April 2019 \\ Available Online: \\ 10 May 2019}

\begin{abstract}
A B S T R A C T
An experiment was conducted to study the effect of water soluble on dwarf coconut at Coconut Research Station, Aliyarnagar. Application of 25, 50, 75, 100 and 125\% of recommended NPK through drip irrigation system was compared with the soil application of recommended NPK as well as control with no fertilizer application. Application of $125 \%$ NPK through drip irrigation resulted in significantly higher Annual leaf production, Number of functional leaves, number of inflorescence and tender nut yield per palm compared to the control and the other fertigation treatments, except $100 \%$ NPK through drip irrigation. Higher nutrient availability in split application of fertilizer through fertigation favours increased nutrient uptake resulting in higher nutrient content in coconut leaves. With respect to economics, gross return (Rs. 302400/ha) and net return (Rs.153400/ha) were significantly higher with the application of drip fertigation of 125 per cent RDF through WSF and it found to be on par with drip fertigation of 100 per cent RDF through WSF. The drip fertigation levels $75 \%$ of RDF through WSF were found to be on par with $100 \%$ RDF through conventional fertilizers application method i.e through soil application. The study indicated the possibility of saving $25 \%$ of the recommended fertilizers by adopting fertigation which ensures higher productivity in coconut than soil application.
\end{abstract}

\section{Introduction}

Coconut is grown in more than 93 countries of the world in an area of 12.29 million ha with a total production in terms of copra equivalent of 11.04 million MT. Indonesia (25.63\%), Philippines (23.91\%), India $(19.20 \%)$ are the major coconut producing countries of the world. India occupies a predominant position in respect of production of coconut in the world. Tamil Nadu produced 6570 million nuts in an area of 461060 ha, with productivity of 14251 nuts per hectare as per CDB statistics in 2016-17. There is a lot of scope for increasing productivity of coconut with better management in the state and thus improving the rural economy. India has one of the largest irrigated areas in the world, but its per-capita as well per-hectare availability of water is one 
of the lowest in the world. The efficient and judicious use of both water and fertilizer is the key for improving agricultural production and productivity in the country. Fertigation (application of water-soluble solid or liquid fertilizer through drip irrigation system) is an attractive method of fertilization in intensive agricultural systems. The drip method of irrigation also helps in reducing overexploitation of groundwater that partly occurs in surface irrigation. Water saving through drip irrigation system is estimated to be in the range of 12-84 per cent in different crops, besides its beneficial impact on crop yields (Narayanamoorthy, 1997). The drip fertigation method has considerable potential to improve water and fertilizer use efficiency. In perennial crops like coconut drip fertigation helps in achieving increased wateruse efficiency, decreased tillage requirement, higher quality products, increased crop yields and higher fertilizer-use efficiency besides saving in water (Sivanappan, 2002 and Namara et al., 2005). With the advent of this new method of irrigation system, traditional method of fertilizer application which is still in practice by the farmers is being slowly replaced by fertigation. Under fertilizer management, fertigation is one of the improved and efficient methods of fertilizer application through which nutrients applied directly to root zone of the plants. By this practice fertilizer may be applied in number of split doses which increase efficiency use of water and fertilizer because this technique prevents leaching of nutrients (Karuna et al, 2019). The annual nutrient export by various parts of the palm viz., nuts, fronds, trunk, bunch and spathe reported by different workers vary from 20 to $174 \mathrm{~kg} \mathrm{~N}, 2.5$ to 20 $\mathrm{kg} \mathrm{P}$ and 35 to $249 \mathrm{~kg} \mathrm{~K} \mathrm{ha}^{-1}$ (Pillai and Davis, 1963). Considering the manurial value of the coconut wastes it would be better to incorporate these wastes in situ if properly shredded. However, scarce research data is available on the performance of dwarf coconut palms under drip fertigation with water soluble fertilizers as source of fertilizers and shredded coconut waste as organic manure. Keeping the above facts in view the present experiment was laid out to study the effect of fertigation on growth and yield of dwarf coconut.

\section{Materials and Methods}

Field experiment was conducted for three consecutive years from during 2015-16, 2016-17, and 2017-18 at Coconut Research Station, TNAU, Aliyarnagar The research station is situated at $10.49^{\circ} \mathrm{N}$ latitude and $77^{\circ}$ E longitude with an altitude of $20 \mathrm{~m}$ above the mean sea level. The soil was sandy loam, non-calcarious, non-saline and neutral in $\mathrm{pH}$. The experiment on intercropping of flower crops in coconut garden was laid out in RBD with three replications. The experiment consisted of eight different levels of water soluble fertilizer was given as treatments viz.,: $\mathrm{T}_{1}-$ Control, $\mathrm{T}_{2}-25 \%$ of RDF through WSF, $\mathrm{T}_{3}-50 \%$ of RDF through WSF, $\mathrm{T}_{4}-75$ $\%$ of RDF through WSF, $\mathrm{T}_{5}-100 \%$ of RDF through WSF, $\mathrm{T}_{6}-125 \%$ of RDF through WSF, $\mathrm{T}_{7}-100 \%$ RDF through conventional fertilizers and $\mathrm{T}_{8}$ - farmers' practice $(20 \mathrm{~kg}$ $\mathrm{FYM}+1 \mathrm{Kg}$ urea $+1 \mathrm{Kg} \mathrm{MOP})$. Fertigation were given 15 years old COD (Chowghat Orange dwarf) garden planted at a spacing of $7.5 \mathrm{~m} \times 7.5 \mathrm{~m}$. The fertilizers were applied through drip fertigation in 12 splits at monthly intervals with Urea, Diammonium phosphate and Muriate of Potash as sources of nitrogen, phosphorus and potassium respectively. Benefit Cost ratio was computed as the present value of benefits divided by the present value of costs by using the following formula

$$
B C R=\frac{\sum_{t=1}^{t=T} \frac{\left(\text { Benefit }{ }_{t}\right)}{(1+r)^{t}}}{\sum_{t=1}^{t=T} \frac{\left(\text { Cost } t_{t}\right)}{(1+r)^{t}}}
$$


where $B_{t}$ is the benefit in time $t$ and $C_{t}$ is the cost in time $t, \mathrm{r}$ is the discount rate.

\section{Statistical analysis}

The experimental data were subjected to statistical analysis in order to find out which of the treatments showed significant variation in different parameters studied under investigation. The technique of analysis of variance (ANOVA) for randomized block design (RBD) was adopted as suggested by Panse and Sukhatme (1967).

\section{Results and Discussion}

\section{Effect of fertigation on growth and yield of dwarf coconut}

The results obtained by the effect of various level fertigation treatments growth and yield were carefully recorded and depicted in Table 1 and Table 2. Annual leaf production, Number of functional leaves and number of inflorescence did not influenced by different fertigation levels at both the 2015-16 and 2016-17. Though the above growth attributes were found to be statistically significant during 2017-18, the variation was found to be minimal. Number of functional leaves (30) and number of inflorescence were higher in drip fertigation of 125 per cent RDF through WSF ( $\mathrm{T}_{6}$ ) were found to be on par with drip fertigation of 100 per cent RDF through WSF $\left(\mathrm{T}_{5}\right)$.

Significantly lowest number of inflorescence (8.5) recorded in control treatment $\left(\mathrm{T}_{1}\right)$. Higher dose of fertilizer through fertigation helped the plants for better uptake of nutrients and consequently the good growth of plant. These results are in confirmation with Honnappa et al., (2017) in fenugreek. These data also supported by the findings of Ramana et al., (2014) who found maximum plant growth when higher NPK dose were supplied in the sweet orange
Highest nut yield (135.6 nuts/palm/year in 2016-17 and 138.4 nuts/palm/year in 201718) recorded in drip fertigation of 125 per cent RDF through WSF ( $\mathrm{T}_{6}$ treatment) and it found to be on par with drip fertigation of 100 per cent RDF through WSF ( $\mathrm{T}_{5}$ treatment). Drip fertigation of 75 per cent RDF through WSF $\left(T_{4}\right)$ were found to be on par with 100 per cent RDF through soil application $\left(\mathrm{T}_{7}\right)$ The per cent increase over the pre-treatment nut yield was more (16.26 per cent) with drip fertigation of 125 per cent RDF through WSF $\left(\mathrm{T}_{6}\right)$ followed by drip fertigation of 100 per cent RDF through WSF $\left(T_{5}\right)$. The treatment without fertilizer application $\left(\mathrm{T}_{1}\right)(-11.93$ per cent) and drip fertigation of 100 per cent RDF through WSF $\left(\mathrm{T}_{2}\right)(-2.79$ per cent) recorded a negative increase over the pre-treatment nut yield.

\section{Economics of fertigation in tender coconut}

Three years of mean data related to economics of different levels of fertigation have been analyzed and presented in Table 3. Gross return worked out based on the mean nut yield of three years and market price of tender nut values. gross return (Rs. 302400/ha) and net return (Rs.153400/ha) were significantly higher with the application of drip fertigation of $125 \%$ of RDF through WSF $\left(\mathrm{T}_{6}\right)$ and it was on par with drip fertigation of 100 per cent RDF through WSF $\left(\mathrm{T}_{5}\right)$. Highest $\mathrm{B}: \mathrm{C}$ ratio of 2.05 recorded in drip fertigation of $100 \%$ of RDF through WSF $\left(\mathrm{T}_{5}\right)$. Lowest net return of Rs. 54640/ha and $\mathrm{B}: \mathrm{C}$ ratio of 1.44 was obtained in the treatment with control plot (shredded coconut waste alone). Higher nut yield with fertigation of $75 \%$ recommended NPK over other fertigation treatments was mainly attributed to increased availability of soil NPK, higher annual leaf production and higher photosynthetic activity and more number of female flower production (Subramanaian et at., 2012; Basavaraju et al., 2014). 
Table.1 Growth attributes of coconut at different levels of fertigation

\begin{tabular}{|c|c|c|c|c|c|c|c|c|c|}
\hline \multirow[t]{2}{*}{ Treatments } & \multicolumn{3}{|c|}{$\begin{array}{l}\text { Annual leaf } \\
\text { production }\end{array}$} & \multicolumn{3}{|c|}{$\begin{array}{c}\text { Number of } \\
\text { functional leaves }\end{array}$} & \multicolumn{3}{|c|}{$\begin{array}{l}\text { Number of } \\
\text { inflorescence }\end{array}$} \\
\hline & $\begin{array}{l}2015- \\
16\end{array}$ & $\begin{array}{l}\text { 2016- } \\
17\end{array}$ & $\begin{array}{l}2017- \\
18\end{array}$ & $\begin{array}{l}2015- \\
16\end{array}$ & $\begin{array}{l}2016- \\
17\end{array}$ & $\begin{array}{l}2017- \\
18\end{array}$ & $\begin{array}{l}2015- \\
16\end{array}$ & $\begin{array}{l}\text { 2016- } \\
17\end{array}$ & $\begin{array}{l}2017- \\
18\end{array}$ \\
\hline $\mathbf{T}_{1}-$ Control & 11.5 & 10.6 & 10.0 & 25.0 & 23.0 & 23.0 & 9.5 & 8.2 & 8.5 \\
\hline $\begin{array}{l}\mathbf{T}_{2^{-}} 25 \% \text { of } \mathrm{RDF} \\
\text { through WSF }\end{array}$ & 11.1 & 11.2 & 11.0 & 23.0 & 22.6 & 23.0 & 9.8 & 9.2 & 9.8 \\
\hline $\begin{array}{l}\mathbf{T}_{3}-50 \% \text { of } \mathrm{RDF} \\
\text { through WSF }\end{array}$ & 11.0 & 11.2 & 11.1 & 25.0 & 25.4 & 28.8 & 10.3 & 10.0 & 10.3 \\
\hline $\begin{array}{l}\mathbf{T}_{4}-75 \% \text { of } \mathrm{RDF} \\
\text { through WSF }\end{array}$ & 11.1 & 11.4 & 11.3 & 25.8 & 26.8 & 28.6 & 10.5 & 10.8 & 10.4 \\
\hline $\begin{array}{l}\mathbf{T}_{\mathbf{5}}-100 \% \text { of } \mathrm{RDF} \\
\text { through WSF }\end{array}$ & 11.6 & 11.8 & 11.2 & 26.8 & 28.4 & 29.5 & 10.6 & 11.0 & 10.6 \\
\hline $\begin{array}{l}\mathbf{T}_{\mathbf{6}}-125 \% \text { of } \mathrm{RDF} \\
\text { through WSF }\end{array}$ & 11.3 & 11.6 & 11.4 & 26.3 & 28.0 & 30.0 & 10.5 & 10.8 & 10.6 \\
\hline 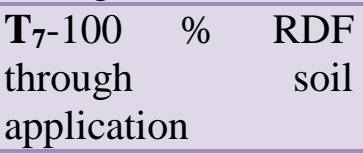 & 11.0 & 11.6 & 11.0 & 26.0 & 27.4 & 28.4 & 10.0 & 10.6 & 10.0 \\
\hline $\mathbf{T}_{\mathbf{8}}$-Farmers' practice & 11.2 & 10.6 & 11.0 & 25.0 & 26.4 & 27.6 & 9.8 & 10.0 & 10.0 \\
\hline SEd & 1.61 & 1.59 & 0.102 & 3.15 & 2.90 & 0.50 & 0.93 & 0.82 & 0.11 \\
\hline$(p=0.05)$ & NS & NS & 0.218 & NS & NS & 1.05 & NS & NS & 0.237 \\
\hline
\end{tabular}

Table.2 Effect of different levels of fertigation on tender nut yield of coconut

\begin{tabular}{|c|c|c|c|c|c|c|}
\hline \multirow[t]{2}{*}{ Treatments } & \multirow{2}{*}{$\begin{array}{l}\text { Pre- } \\
\text { treatment } \\
\text { tender nut } \\
\text { yield }\end{array}$} & \multicolumn{3}{|c|}{ Annual tender nut yield } & \multirow{2}{*}{$\begin{array}{l}\text { Cumulative } \\
\text { mean nut } \\
\text { yield }\end{array}$} & \multirow[t]{2}{*}{$\%$ Increase } \\
\hline & & 2015-16 & 2016-17 & 2017-18 & & \\
\hline $\mathbf{T}_{1}-$ Control & 112.0 & 105.3 & 98.2 & 92.4 & 98.63 & -11.93 \\
\hline $\mathrm{T}_{2-} 25 \%$ of RDF through WSF & 115.8 & 115.4 & 112.3 & 110.0 & 112.57 & -2.79 \\
\hline $\mathrm{T}_{3}-50 \%$ of RDF through WSF & 117.0 & 119.0 & 121.4 & 124.0 & 121.80 & 4.10 \\
\hline $\mathrm{T}_{4}-75 \%$ of RDF through WSF & 115.2 & 120.3 & 125.2 & 130.2 & 125.57 & 9.00 \\
\hline$T_{5}-100 \%$ of RDF through WSF & 116.6 & 128.8 & 133.8 & 136.2 & 132.93 & 14.01 \\
\hline $\mathrm{T}_{6}-125 \%$ of RDF through WSF & 115.6 & 129.2 & 135.6 & 138.4 & 134.40 & 16.26 \\
\hline $\begin{array}{l}\mathrm{T}_{7-100} \% \mathrm{RDF} \text { through soil } \\
\text { application }\end{array}$ & 116.8 & 120.4 & 124.6 & 129.8 & 124.93 & 6.96 \\
\hline $\mathbf{T}_{8}$-Farmers' practice & 110.2 & 112.6 & 114.8 & 113.6 & 113.67 & 3.15 \\
\hline SEd & - & 12.75 & 2.88 & 2.77 & 4.26 & - \\
\hline $\begin{array}{l}\text { CD } \\
(p=0.05)\end{array}$ & - & NS & 6.175 & 5.914 & 9.134 & - \\
\hline
\end{tabular}


Table.3 Economics of fertigation in tender coconut (Mean of 3 years)

\begin{tabular}{|c|c|c|c|c|}
\hline Treatments & $\begin{array}{l}\text { Gross } \\
\text { returns } \\
\text { (Rs./ha) }\end{array}$ & $\begin{array}{c}\text { Cost of } \\
\text { cultivation } \\
\text { (Rs./ha) }\end{array}$ & $\begin{array}{l}\text { Net } \\
\text { returns } \\
\text { (Rs./ha) }\end{array}$ & $\begin{array}{l}\text { B:C } \\
\text { Ratio }\end{array}$ \\
\hline $\begin{array}{l}T_{1} \text { - Control (shredded coconut waste } \\
\text { alone) }\end{array}$ & 186640 & 130000 & 56640 & 1.44 \\
\hline $\begin{array}{l}T_{2}-25 \% \text { of } \mathrm{RDF} \text { through WSF + } \\
\text { shredded coconut waste }\end{array}$ & 253275 & 136400 & 116875 & 1.86 \\
\hline $\begin{array}{l}\mathrm{T}_{3}-50 \% \text { of } \mathrm{RDF} \text { through WSF + } \\
\text { shredded coconut waste }\end{array}$ & 272550 & 139750 & 132800 & 1.95 \\
\hline $\begin{array}{l}\mathrm{T}_{4}-75 \% \text { of RDF through WSF + } \\
\text { shredded coconut waste }\end{array}$ & 282533 & 143000 & 139533 & 1.98 \\
\hline $\begin{array}{l}T_{5}-100 \% \text { of } \mathrm{RDF} \text { through WSF + } \\
\text { shredded coconut waste }\end{array}$ & 299100 & 146000 & 153100 & 2.05 \\
\hline $\begin{array}{l}\mathrm{T}_{6}-125 \% \text { of } \mathrm{RDF} \text { through } \mathrm{WSF}+ \\
\text { shredded coconut waste }\end{array}$ & 302400 & 149000 & 153400 & 2.03 \\
\hline $\begin{array}{l}\mathrm{T}_{7}-100 \% \mathrm{RDF} \text { through conventional } \\
\text { fertilizers + shredded coconut waste }\end{array}$ & 281093 & 142000 & 139093 & 1.98 \\
\hline $\mathbf{T}_{8}$-Farmers' practice & 221925 & 132000 & 89925 & 1.68 \\
\hline SEd & 4497.76 & - & 3105.41 & 0.021 \\
\hline $\mathrm{CD}(\mathrm{p}=\mathbf{0 . 0 5})$ & 9647.77 & - & 6661.17 & 0.044 \\
\hline
\end{tabular}

The drip fertigation level $75 \%$ of $\mathrm{RDF}$ through WSF $\left(\mathrm{T}_{4}\right)$ was found to be on par with $100 \%$ RDF through conventional fertilizers application method i.e through soil application. A fertilizer saving of 25 per cent is possible by adopting fertigation with 75 per cent NPK through drip irrigation compared with 100 per cent RDF through soil application.

\section{References}

Basavaraju, T.B., Bhagya, H.P., Prashantb, M., Arulraj, S. and Maheswarappa, H.P. 2014. Effect of fertigation on the productivity of coconut. Journal of Plantation Crops 42(2): 198-204.

CDB. 2018. All India Final Estimates of Area and Production of Coconut 2016-17. Coconut Development Board, Kochi, Kerala

Honnappa A., Harisha, C. B. and Ravindra
Singh. 2017. Precision irrigation and fertigation for higher productivity and water use efficiency in fenugreek (Trigonella foenum-graecum 1.) in semi arid conditions of Rajasthan. The Bioscan, 12(1): 591-594

Karuna, K., Abhay Mankar, Ghanshyam Singh and Feza Ahmad. 2019. Effect of fertigation on growth, phenology and nutrient status in leaves under high density orchard of Citrus sinensis Osbeck cv. Mosambi. Int.J.Curr.Microbiol.App.Sci. $\quad 8(04)$ : 202-210.

Namara, Regassa E., Upadhyay, Bhawana and Nagar, R. K. 2005. Adoption and Impacts of Microirrigation Technologies: Empirical Results from Selected Localities of Maharashtra and Gujarat States of India, Research Report 93, International Water Management Institute, Colombo, Sri Lanka 
Narayanamoorthy, A. 1997. "Economic Viability of Drip Irrigation: An Empirical Analysis from Maharashtra", Indian Journal of Agricultural Economics, Vol. 52, No. 4, OctoberDecember, pp. 728-739

Panse, V.G. and Sukhatme, P.V. 1967. Statistical methods for agricultural workers, Indian Council of Agricultural Research, New Delhi

Pillai, N. G. and Davis, T. A. 1963. Exhaust of macro-nutrients bythe coconut. A preliminary study. Indian Coconut Journal, 16: 81-87.

Ramana, K.T.V., Lakshmi, L.M., Gopal, K., Krishna, V.N.P.S., Lakshmi, T., Sarada, G., Gopi, V. and Sankar, T.G. 2014. Nitrogen and Potassium Based Fertigation Response on Plant Growth, Yield and Quality of Sweet Orange (Citrus sinensis Osbeck) cv. Sathgudi. Research and Reviews: J. Agric. Allied Sci., 3(3

Sivanappan, R.K.2002. Strengths and weaknesses of growth of drip irrigation in India, In: Proc. of Micro Irrigation for Sustainable Agriculture. GOI Shortterm training 19-21 June, WTC, Tamil Nadu Agricultural University, Coimbatore.

Subramanian, P., Dhanapal, R., Mathew, A.C., Palaniswami, C., Upadhyaya, A.K., Naresh Kumar, N. and Reddy, D. 2012. Effect of fertilizer application through micro-irrigation technique on nutrient availability and coconut productivity. Journal of Plantation Crops 40(3): 168-173.

Wassel, A.H., Ahmed, F.F., Ragab, M.A. and Ragab, M.M. 2007. Response of Balady mandarin trees to drip irrigation and nitrogen fertigation II- Effect of nitrogen fertigation and drip irrigation on fruit setting, number and quality of fruits of Balady mandarin trees (Citrus reticulata). Afric. Crop Sci. Conf. Proc., 8: 513-522.

\section{How to cite this article:}

Rani, S., C. Sudhalakshmi, K. Venkatesan and Maheshwarappa, H.P. 2019. Effect of Fertigation on Productivity and Economics of Dwarf Coconut cv. Chowghat Orange Dwarf (COD). Int.J.Curr.Microbiol.App.Sci. 8(05): 1163-1168. doi: https://doi.org/10.20546/ijcmas.2019.805.132 